\title{
Wheat Oxygen Evolving Enhancer Protein: Identification and Characterization of Mn-Binding Metalloprotein of Photosynthetic Pathway Involved in Regulating Photosytem II Integrity and Network of Antioxidant Enzymes under Heat Stress
}

\author{
Ansif Ali ${ }^{1}$, Suneha Goswami ${ }^{*}$, Ranjeet R. Kumar ${ }^{1}$, Khushboo Singh ${ }^{1}$, \\ Jyoti P. Singh ${ }^{1}$, Ashok Kumar ${ }^{1}$, Arti Kumari ${ }^{1}$, Akshay Sakhrey ${ }^{2}$, \\ Gyanendra K. Rai ${ }^{3}$ and Shelly Praveen ${ }^{1 *}$
}

\begin{abstract}
${ }^{1}$ Division of Biochemistry, Indian Agricultural Research Institute, New Delhi, India ${ }^{2}$ Division of Plant Physiology, Indian Agricultural Research Institute, New Delhi, India

${ }^{3}$ School of Biotechnology, Sher-e-Kashmir University of Agricultural Sciences and Technology of Jammu, India
\end{abstract}

*Corresponding author

\section{A B S T R A C T}

\section{Keywords}

Catalase, Heat stress, Peroxidase, photosynthetic rate, IRGA, PsbO, qRTPCR, Superoxide dismutase, Total antioxidant activity

Article Info

Accepted:

04 January 2018

Available Online:

10 February 2018
PsbO is a ubiquitous extrinsic protein of photosystem II required for providing proper environment for water splitting activity of photosystem II. Exposure of wheat to heat stress initially reduces the rate of photosynthesis by disintegrating the photosystem II, primarily by disruption of the oxygen evolving complex (OEC). Here, we identified and cloned putative PsbOgene of $1 \mathrm{~kb}$ from wheat cv. HD2329 using de novo assembly. Expression analysis showed higher expression of PsbO transcript in HD2985, as compared to HD2329 during pollination and grain-filling stages. We observed significant variations in the expression of $P s b O$ in response to differential HS. A positive correlation was established between the expression of $P s b O$ and activity of antioxidant enzymes like superoxide dismutase, catalase and guaiacol peroxidase in response to heat stress in contrasting wheat $c v s$. at different stages of growth. Photosynthetic rate was observed slightly higher in thermotolerant cultivar at different stages, as compared to susceptible. There is, however, need to discover many more isoforms of $P s b O$ from wheat in order to characterize their role in the modulation of carbon assimilatory pathway under heat stress. Maintaining the integrity of PSII under HS using PsbO will pave the way for the development of 'climatesmart' wheat.

\section{Introduction}

Photosynthesis is the most sensitive physiological process at elevated temperature (Wahid et al., 2007).Exposure of cereals to long term high temperature results in a reduction in photochemical efficiency of Photosystem II (PS II) due to photo inhibition and damage to chloroplast (Hasanuzzaman et al., 2013). Heat stress drastically reduces the rate of photosynthesis by disintegrating the photosystem II (Sharkey, 2005). Photosystem 
II complex is a heat-labile pigment-protein complex which is involved in the electron transport of the photosynthetic process and responsible for the light-induced water oxidation to produce molecular oxygen. The heat induced inactivation of this complex is caused principally by dissociation of the oxygen evolving complex (OEC) (Kimura et al., 2002). The activity of the Oxygen Evolving Complex (OEC) of PS II is often lost before the rest of the reaction centre loses its activity (Aro et al., 1993). The largest extrinsic subunit protein of photosystem II (PSII) is PsbO. It is the second abundant hydrophilic protein on the world, which is next to the most abundant RuBisCO subunit protein (Henmi et al., 2004). Evidence suggests that $\mathrm{PsbO}$ protein have important role in regulation of PSII activity. Removal of PsbO leads to destabilise Mn-cluster and Mn ions are released (Enami et al., 2000), for that reason this protein is also called ' $\mathrm{Mn}$ stabilising protein' Bricker, (1992) reported that PsbO protein functions to control the chloride and calcium requirements for oxygen evolution. The oxygen evolution requirements for both of these ions are significantly lowered in the presence of the PsbO component. Evidence has been presented that the PsbO protein binds GTP with high affinity and functions as a GTPase (Lundin et al., 2007). In this role, it has been predicted in controlling the phosphorylation state of the D1 protein (Lundin et al., 2007a). Since the phosphorylation level of the D1 component appears to be coupled with its efficient PS II turnover, it was proposed that the PsbO protein may be an important regulatory component of this process (Lundin et al., 2008). McConnell et al., (2007) reported that the association of carbonic anhydrase activity with PS II is highly variable.Carbonic anhydrase activity associated with PS II membranes has lost upon purification of an oxygen-evolving PS II core complex which contained the PsbO component.Kim et al.,
(2015), it was found that PsbO had higher $\mathrm{H}_{2} \mathrm{O}_{2}$ scavenging activity, which proved to be the result of enzymatic antioxidants rather than non-enzymatic antioxidants. It was found that PsbO act as a structural template and a sensor of the hydrogen-bonding network which is required for proper water oxidation of photosystem (Offenbacher et al., 2013). Recently, Takahashi et al., (2017) reported that PsbO is the only protein nitrated when Arabidopsis thaliana thylakoid membranes are incubated in a buffer bubbled with nitrogen dioxide $\left(\mathrm{NO}_{2}\right)$ that leads to the inactivation of photosystem II. The mutation in aspartic acid (D157) in the $P s b O$ gene encoding the photosystem II Manganese-stabilizing protein from spinach, exhibit near-wild-type PSII binding mechanisms, but are significantly impaired in $\mathrm{O}_{2}$ evolution activity and $\mathrm{Cl}^{-}$ retention by PSII (Popelkova et al., 2009).

The growing threat of climate change is already having a considerable influence on agricultural production worldwide as heat stress cause significant yield losses with great challenges for future food security (Christensen and Christensen, 2007). Wheat (Triticum aestivum L.) is a staple food crop which is very sensitive to high temperature (Slafer and Satorre 1999). It was reported that in some wheat varieties there is a loss of 10$15 \%$ of yield with an increase of every $5^{\circ} \mathrm{C}$ in temperature (Burrell 2003). Quality and quantity of wheat grains is also reduced by heat stress (Viswanathan and Khanna-chopra 2001). Photosynthesis is harmfully affected by heat stress in a number of ways (Kumar et al., 2016). In that Oxidative stress is a major outcome that leads to the formation of hydroxyl radicals $\left(\mathrm{OH}^{-}\right)$, superoxides $\left(\mathrm{O}_{2}^{-}\right)$and hydrogen peroxide $\left(\mathrm{H}_{2} \mathrm{O}_{2}\right)$ which are commonly called reactive oxygen species.Hence, their detoxification by antioxidant systems is important for protecting plants against heat stress (Asada, 2006; Suzuki and Mittler, 2006). Otherwise the ROS may 
involved in destroying D1 protein of photosytem II (Yamamoto et al., 2008), and inhibits the repairing of photodamaged PSII (Murata et al., 2007), that leads to inactivating of PSII (Yamashita et al., 2008). This stress associated ROS toxicity considered to be one of the key reason of decreased crop productivity (Vadez et al., 2012).

In present investigation, we have identified, cloned and characterized a novel PsbO gene from wheat $c v$. HD2329 and correlation was established between the expression of $\mathrm{PsbO}$ and different biochemical and physiological parameters under HS.

\section{Materials and Methods}

\section{Plant material and heat stress treatment}

Two wheat cultivars i.e. HD2985 and HD2329 were used in this study. Seeds were sown in 18 pots (nine for each variety) having equal quantity of perlite to FYM mixture inside the regulated chamber (temperature $22 \pm 3^{\circ} \mathrm{C}$; relative humidity of $75 \%$ and 8 hours) in the National Phytotron Facility, IARI, New Delhi. Irrigation was done at regular intervals, and plants at the pollination and grain-filling stage were selected (based on the Feekes scale; three pots from each variety) were exposed to heat stress of $30^{\circ} \mathrm{C}$ and $38^{\circ} \mathrm{C}$ for $1 \mathrm{~h}$, whereas other three pots in each group served as control $\left(22 \pm 3^{\circ} \mathrm{C}\right)$. The heat stress was given in a sinusoidal mode using microprocessorregulated controller with an increase of $1^{\circ} \mathrm{C} / 10$ minutes till the temperature reaches the $30^{\circ}$ or $38^{\circ} \mathrm{C}$, and it was maintained for 1 hours.. Samples were collected in triplicates from both the cultivars frozen in liquid nitrogen for further downstream analysis.

\section{Isolation and cloning of $P s b O$ from Wheat}

An RNA-Seq experiment was executed in our lab for the identification of novel heat- responsive stress-associated genes in wheat cvs. HD2985 and HD2329 at developing stage using de novo transcriptome sequencing on Illumina HiSeq 2000 platform. The raw data generated using Next-Generation Sequencing (NGS) of control and HS treated samples of HD2985 and HD2329 cultivars of wheat (NCBI BioProject Database: PRJNA171754) was assembled using Velvet and Oases v 2.0 and was mined for the identification of $P s b O$ transcripts based on the presence of conserved domain in the transcripts as well as homology based search. Transcript predicted to be PSBO gene (identified by data mining) were used for designing primers. Transcript specific primers were designed using Genefisher2 primer designing software, and the quality of the oligos was checked using Oligo Analyzer (Integrated DNA Technologies, USA) (Table 1). Total RNA was extracted from the leaves of wheat cv. HD2329 using Trizol reagent (Invitrogen, UK). Quality of isolated RNA was checked using Nanodrop (Thermo Fischer Scientific, USA). CDNA synthesis was carried out by using Revert Aid H Minus First stand cDNA synthesis kit (Fermentas, UK) as per the instruction given by the manufacturer's. The quality of cDNA was checked on $1 \%$ agarose gel. RT-PCR amplification was carried out using the cDNA template by using transcript specific primers. The amplified product was purified using the PCR cleanup kit (Promega, USA), and ligated into pGEM-T Easy vector using ligase enzyme (Promega, USA) and transformation using E. coli $\mathrm{DH} 5 \alpha$ competent cells. The cloned genes were sequenced using Sanger's di-deoxy method.

\section{In silico analysis of $P s b O$ gene}

The sequenced genes were subjected to nucleotide based homology search using BLASTn tool of NCBI (http://blast.ncbi.nlm. nih.gov/). Similarly, BLASTp was also carried out to know the homology at protein level. The Expasy tool (http://www.expasy.org/) was 
used to find out the amino acid sequence and further Simple Modular Architecture Retrieval Tool (SMART) search (http://smart.emblheidelberg.de/) was used to find out the conserved domain in the sequence. Rampage was used to confirm predicted protein structure. iPSORT was used for sub cellular localization. Ensemble Plant tools were used for chromosomal localization of gene. ProtParam was used for computation of several physical and chemical parameters. ORFfinder NCBI was used for identification of open reading frame of cloned gene. Protein 3D modeling was done using PHYRE2 Protein Fold Recognition Server.

\section{RNA extraction and quantitative real time PCR (qRT-PCR)}

Total RNA was isolated using Trizol method from both cultivars from control and HStreated samples. CDNA synthesis was carried out by using Revert Aid H Minus First stand cDNA synthesis kit (Fermentas, UK), and quality and quantity was ensured by using Nanodrop. Quantitative RT-PCR was carried out by using KAPA SYBR Green qPCR master mix on a Bio-Rad CFX96 machine. Wheat $\beta$-Actin gene (accession no.AF282624) was used as the internal control gene. Relative expression levels of $P s b O$ gene was quantified by using the $2^{-\Delta \Delta \mathrm{Ct}}$ method (Pfaffl, 2001).

\section{Measurement of photosynthetic rate}

Wheat cvs. HD2329 and HD2985 were used for the IRGA analysis under control $\left(22 \pm 3^{\circ} \mathrm{C}\right)$ and $\mathrm{HS}\left(30^{\circ} \mathrm{C}\right.$ and $\left.38^{\circ} \mathrm{C}, 2 \mathrm{~h}\right)$ during the pollination and grain-filling stage (Feekes 11.1). The plants were subjected to infra-red gas analyzer (IRGA) for analyzing the effect of HS on the photosynthesis (LiCor 6400, LiCor Inc., USA), and the observations were recorded following Long and Bernacchi, (2003). Fully expanded flag leaf was used for the IRGA analysis, and the readings were taken in triplicates between 11 am to $12 \mathrm{pm}$. Photosynthesis was measured at constant saturating light of $1500 \mu \mathrm{mol} \mathrm{m} \mathrm{m}^{-2} \mathrm{~s}^{-1}$. Measurements of leaf $\mathrm{R}$ dark were made on dark-adapted leaves after $30 \mathrm{~min}$ of dark adaptation to achieve steady- state $\mathrm{R}$ dark. The calculation was carried out as per suggested protocol by Kumar et al., (2017).

\section{Estimation of antioxidant enzymes}

\section{Guaiacol peroxidase (GPX) activity assay}

Samples (control and heat stressed sample) collected from wheat cvs.HD2329 and HD2985were used for the guaiacol-peroxidase (GPX) activity assay following the method of Evers et al., (1994) with slight modification. Fresh leaf material $(1 \mathrm{~g})$ was crushed in $5 \mathrm{~mL}$ of ice-cold $50 \mathrm{mM}$ potassium phosphate buffer ( $\mathrm{pH} 7.0$ ) containing $2 \mathrm{mM}$ sodium-EDTA and $1 \%$ (w/v) polyvinyl-pyrrolidone (PVP). The homogenates were centrifuged at $10,000 \mathrm{~g}$ $\left(4^{\circ} \mathrm{C}\right)$ for $10 \mathrm{~min}$. The tissue extracts were used for the quantification of soluble protein content and analysis of peroxidase activity. Coomassie blue dye-binding assay was used for protein estimation and bovine serum albumin (BSA) for standard curve preparation. The oxidation of guaiacol into tetraguaiacol was estimated by measuring the absorbance at $470 \mathrm{~nm}$ against the reagent blank, using extinction coefficient of $26.6 \mathrm{mM}^{-1} \mathrm{~cm}^{-1}$.

\section{Estimation of superoxide dismutase activity}

The samples (Control and heat stressed sample) collected from wheat $c v s$.HD2329 and HD2985were used for the SOD activity assay based on the Nitrobluetetrazolium (NBT) method. The assay mixture contained $1.2 \mathrm{ml}$ of sodium pyrophosphate buffer, $0.1 \mathrm{ml}$ of PMS, $0.3 \mathrm{ml}$ of NBT, $0.2 \mathrm{ml}$ of the enzyme preparation and water in a total volume of 2.8 $\mathrm{ml}$. The reaction was initiated by the addition of $0.2 \mathrm{ml}$ of $\mathrm{NADH}$. The mixture was 
incubated at $30^{\circ} \mathrm{C}$ for 90 seconds and arrested by the addition of $1.0 \mathrm{ml}$ of glacial acetic acid. The reaction mixture was then shaken with $4.0 \mathrm{ml}$ of $\mathrm{n}$-butanol, allowed to stand for 10 minutes and centrifuged. The intensity of the chromogen in the butanol layer was measured at $560 \mathrm{~nm}$ in a spectrophotometer. One unit of enzyme activity is defined as the amount of enzyme that gave $50 \%$ inhibition of NBT reduction in one minute.

\section{Catalase activity assay}

Activities of catalase enzyme were measured as described by Chance and Maehly, (1955). Fresh leaf material $(1 \mathrm{~g})$ was crushed in $5 \mathrm{~mL}$ of ice-cold $50 \mathrm{mM}$ potassium phosphate buffer (pH 7.0) containing $2 \mathrm{mM}$ sodium-EDTA and $1 \%$ (w/v) polyvinyl-pyrrolidone (PVP). The homogenates were centrifuged at $10,000 \mathrm{~g}$ $\left(4^{\circ} \mathrm{C}\right)$ for $10 \mathrm{~min}$. The tissue extracts were used for the quantification of soluble protein content by using Bradford method and analysis of catalase activity. Catalase activity was measured in a reaction mixture $(3 \mathrm{~mL})$ containing $100 \mathrm{mM} \mathrm{Na}_{2} \mathrm{HPO}_{4}$ buffer $\mathrm{pH} 6.8$ (2 $\mathrm{mL}), 30 \mathrm{mM} \mathrm{H} \mathrm{O}_{2}(0.5 \mathrm{~mL})$ and $0.5 \mathrm{~mL}$ enzyme. For assaying CAT activity, the decomposition of $\mathrm{H}_{2} \mathrm{O}_{2}$ was followed by decline in the absorbance at $240 \mathrm{~nm}$ as catalase enzyme catalyzes the reaction.

\section{Estimation of total antioxidant capacity}

The FRAP (Ferric reducing antioxidant power assay) procedure for estimating total antioxidant activity was followed as described by Benzie and Strain (1999) with slight modification. Aliquots of $100 \mu \mathrm{L}$ sample were mixed with $3 \mathrm{~mL}$ FRAP reagent and the absorbance of the reaction mixture at $593 \mathrm{~nm}$ was measured spectro photometrically after incubation at $37^{\circ} \mathrm{C}$ for $10 \mathrm{~min}$. For the calibration curve, five different concentration of $\mathrm{FeSO}_{4} \cdot 7 \mathrm{H}_{2} \mathrm{O}(100,750,500,250$ and 125 $\mu \mathrm{mol} / \mathrm{L})$ were used and the absorbance were measured at $593 \mathrm{~nm}$. The values were expressed as the concentration of antioxidants having a ferric reducing ability equivalent to that of $1 \mathrm{mmol} / \mathrm{L} \mathrm{FeSO}_{4}$.

\section{Results and Discussion}

\section{Molecular cloning and in-silico characterization of candidate $P s b O$ gene}

Whole transcriptome sequencing of wheat was carried out in our lab for the identification of novel heat-responsive genes at grain-filling stage using de novo assembly. This NGS data was mined for the identification of novel PsbO transcripts based on the domain search and homology with $P s b O$ gene. The identified PsbO transcripts mined from the NGS data were characterized for their Digital Gene Expression (DGE). Based on the DGE, transcript (CDS_52998_unigene_92869) which showing maximum DGE, targeted for the cloning. Transcript-specific forward and reverse primers were used along with cDNA template synthesized from the HS-treated HD2329 for the RT-PCR. The amplicon was excised from the gel, purified and the purified amplicon was ligated in pGEM-T Easy vector and transformed in $E$. coli DH5 $\alpha$ strain. Positive colonies were selected based on the blue white colony selection. The isolated plasmids were subjected to restriction analysis (RE: EcoRI) in order to check the release of the target $P s b O$ gene. We observed release of $\sim 1.0 \mathrm{~kb}$ fragment from the plasmid on $0.8 \%$ agarose gel. The isolated plasmid showing release of target gene was sent for the sequencing by Sanger's di-deoxy method. Sequencing followed by curing showed the presence of 987 nucleotides in the amplified sequence. BLASTn (NCBI) search showed maximum homology with Triticum aestivum cDNA clone WT007 L07 cultivar: Chinese spring (acc. no. AK331517.1) followed by Aegilopstauschii subsp. Tauschii Oxygen evolving enhancer protein 1, chloroplastic 
(LOC109772509) mRNA, (acc. no. XM020331189.1). BLASTp analysis showed maximum (100\%) homology with Oxygen evolving enhancer protein 1 reported from Aegilopstauschii subsp. Tauschii (acc. no. XP 02018677778.1) followed by $99 \%$ with Predicted protein reported from Hordeumvulgare subsp. vulgare (acc. no. BAJ89638.1). Gene sequence was submitted in National Centre for Biotechnology Information (NCBI) GenBank with acc. no. KY014425.

Open reading frame was predicted using ORF finder (NCBI), A total of 6 ORF were predicted, longest ORF was of 987 base pairs (bp) spanning from 1 to $987 \mathrm{bp}$ which encodes for 328 amino acids. Conserved domain search showed the presence of MSP (Manganese stabilizing protein) superfamily (accession no. PLN00037) with a bit score of 486.40 and Conserved Domain length of 232 amino acids (Fig. 1a). The cloned $P s b O$ gene sequence was mapped on to the genome of Triticum aestivum available in Ensembl plants (http://plants.ensembl.org/

Triticum_aestivum), and was observed to be localized on the chromosome 2B. Further, the amino acid sequence of the cloned gene was obtained through Expasy translate tool, and the sequence used for the prediction of the protein model using Protein Homology Analogy Recognition engine 2.0 (Phyre 2.0). The PsbO protein showed the presence of $14 \%$ $\alpha$-helices, $42 \% \quad \beta$-strand and $56 \%$ disorder structure, which validates the report of (Svensson et al., 2002; Popelkova et al., 2009). Protein was modelled based on template model of cryo-em structure of spinach photosystem2-light harvesting complex 2(psii-lhcii) (Fig. 1b). 22 serine residues, 12 tyrosine and 3 threonine were predicted to be phosphorylation site in the putative protein using NetPhos 3.1 server (http://www.cbs.dtu.dk/services/NetPhos/).

these predicted sites in this cloned gene confirms the earlier report by Yang et al., (2003) and Lundin et al., (2007) who reported that PsbO protein is regulated by phosphorylation. (Fig. 1c). In Physical and chemical properties of protein, theoretical pI was found to be 5.75 and aliphatic index 70.58, instability index 37.05 was retrieved through Expasy Protparam tool. Chloroplastic transit peptide sequence of 21 amino acids was observed on protein which shows their cellular localization. Existence of the predicted protein structure was confirmed by using rampage in which $98 \%$ of amino acid residue comes under the favored region of Ramchandran plot (Fig. 1d).

\section{Expression profiling of $\mathrm{Ps} b O$ gene in wheat under heat stress}

The cloned $P s b O$ gene was characterized for their expression during pollination and grain filling stage under differential heat stress in thermotolerant (HD2985) and thermosusceptible (HD2329) $c v$. of wheat using quantitative Real-Time PCR (qRTPCR). Total RNA was isolated from freshly harvested leaf samples and purity was checked on $1.2 \%$ denaturing agarose gel. In pollination stage relative expression of putative $\mathrm{PsbO}$ transcripts was observed at $30^{\circ} \mathrm{C}$ for $1 \mathrm{~h}$ in both the $c v$.; percent increase was observed significantly higher in thermotolerant cultivar, HD2985, as compared to thermosusceptible, HD2329. In pollination stage wheat cultivar HD2985 showed relative expression of 1.74 fold in response to $\mathrm{HS}$ of $30^{\circ} \mathrm{C}$ for $1 \mathrm{~h}$, as compared to control. Similarly, thermosusceptible $c v$. HD2329 showed 1.54fold increase in the expression. Similarly, we observed 1.90 fold increase in the expression and 1.59 fold in HD2329 HD2985 in response to $38^{\circ} \mathrm{C}, 2 \mathrm{~h}$ during pollination stage. Similar pattern was observed during grain-filling stage. HD2985 showed relative expression of 2.0 fold in response to $\mathrm{HS}$ of $30^{\circ} \mathrm{C}$ for $1 \mathrm{~h}$, as compared to control (Fig. 2). HD2329 showed 
1.93-fold increase in the expression under HS of $30^{\circ} \mathrm{C}$ for $1 \mathrm{~h} . \mathrm{HD} 2985$ during grain-filling showed expression of 2-fold in response to HS of $38^{\circ} \mathrm{C}$ for $1 \mathrm{~h}$. Similarly, HD2329 showed 1.75 -fold increase in the expression in response to $\mathrm{HS}$ of $38^{\circ} \mathrm{C}$ for $1 \mathrm{~h}$. Pawlowicz et al., (2012) observed that increase in the accumulation of $P s b O$ gene in Tall fescue (Festuca arundinacea) in response to drought stress. A significant, positive, and linear correlation has been reported by Liu et al., (2015) in which they have showed the increase in digital fold expression of $P s b O$ gene under heat and drought stress in wheat. Choulet et al., (2014) also reported the increased digital expression of $P s b O$ gene in different tissues of wheat.

Alterations in the photosynthesis-associated parameters in wheat under $\mathrm{HS}$

We observed significant decrease in the photosynthetic rate in response to heat stress in both the cvs. HD2985 and HD2329. Decrease in photosynthetic rate wasobserved more in the thermotolerant cultivar (HD2985) at both stages, as compared to thermosusceptible cultivar HD2329 (Fig. 3). Percentage decrease in photosynthetic rate $\left(\mathrm{P}_{\mathrm{i}}\right)$ of HD2329 was significantly lower, as compare to HD2985. Farooq et al., (2011) also reported decrease in the photosynthetic capacity of the plant under HS. Kumar et al., (2016) and Chen et al., (2017) recently reported the decrease in photosynthetic rate in wheat in response to heat stress and they also correlated it with activity of various antioxidant enzymes.

\section{Guaiacol peroxidase (GPX) activity assay}

We observed an increase in guaiacol peroxidase (GPX) activity in both the $c v s$. and with successive treatments. The activity was observed more in thermotolerant cv. HD2985 than thermosusceptible HD2329. In both the stages i.e. pollination and grain-filling, the activity was higher with successive treatment of HS in both the cultivars. In HD2985, the specific activity of Guaiacol peroxidase (GPX) was observed maximum $(168.29 \mu \mathrm{mol}$ $\min ^{-1} \mathrm{mg}^{-1}$ protein) at $38^{\circ} \mathrm{C}$ for $1 \mathrm{~h}\left(\mathrm{~T}_{2}\right)$ and minimum of $95.81 \mu \mathrm{mol} \mathrm{min}{ }^{-1} \mathrm{mg}^{-1}$ protein in control at pollination stage. During grainfilling stage, maximum Gpx of $178.59 \mu \mathrm{mol}$ $\mathrm{min}^{-1} \mathrm{mg}^{-1}$ protein was observed in response to

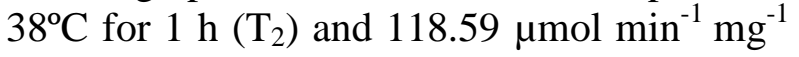
protein in control (Fig. 4). HD2329 showed maximum activity of $110.74 \mu \mathrm{mol} \mathrm{min}^{-1} \mathrm{mg}^{-1}$ protein and a minimum of $85.93 \mu \mathrm{mol} \mathrm{min}{ }^{-1}$ $\mathrm{mg}^{-1}$ protein at pollination stage. During grainfilling, maximum of $151.1 \mu \mathrm{mol} \mathrm{min} \mathrm{mg}^{-1}$ protein and minimum of $97.63 \mu \mathrm{mol} \mathrm{min}^{-1} \mathrm{mg}^{-}$ ${ }^{1}$ protein was observed in response to $38^{\circ} \mathrm{C}$ for $1 \mathrm{~h}\left(\mathrm{~T}_{2}\right)$ and control, respectively. Chen et al., (2017) also reported increase in the GPX activity in response to heat stress in wheat.

Table.1 List of primers used for the cloning and expression analysis of oxygen evolving enhancer protein gene identified from wheat using de novo assembly

\begin{tabular}{|l|l|l|}
\hline primers & Primer sequence $\left(\mathbf{5}^{\circ}-\mathbf{3}^{\circ}\right)$ & Tm $\left({ }^{\circ} \mathrm{C}\right)$ \\
\hline Psb0-f & ATGGCAGCGTCTCTCCAAG & 59.5 \\
\hline PsbO-r & CTAGTTAGACTCGAGCTGCG & 60.5 \\
\hline qPsbO-f & CCAGAGCAAGACCTACATGG & 58 \\
\hline qPsbO-r & CCATCTCGTCAAGGGTGTAG & 58 \\
\hline Act-f & GCGGTCGAACAACTGGTATT & 58.4 \\
\hline Act-r & GGTCCAAACGAAGGATAGCA & 58.4 \\
\hline
\end{tabular}


Fig.1a Conserved domain prediction of putative PsbO gene cloned from HD2329 cv. of wheat using Conserved Domain search tool of NCBI

(http://www.ncbi.nlm.nih.gov/Structure/cdd/wrpsb.cgi)

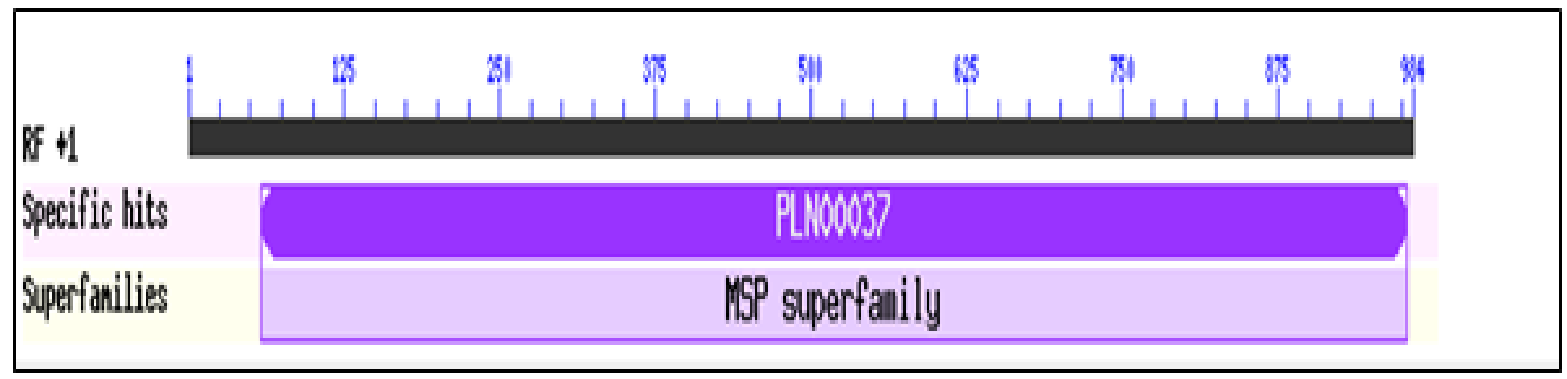

Fig.1b Predicted protein model of putative cloned $P s b O$ gene from wheat cv HD 2329

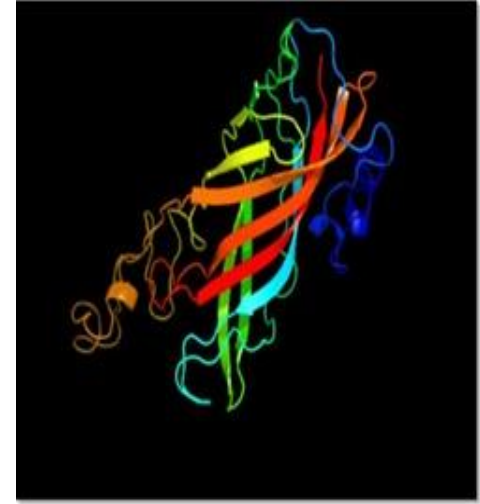

a) Protein structure of $P s b O$ gene

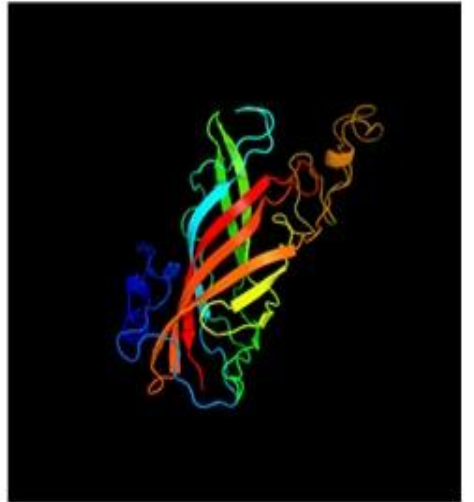

b) Structure of PsbO protein reported from spinacia oleracia which was $\mathrm{u}$ prediction. (http//www.sbg.bio.ic.ac.uk/phyre2/html/p age.cgi?id=index)

Fig.1c Predicted phosphorylation site on putative $P s b O$ gene cloned from HD2329 cultivar of wheat using NetPhos 3.1 (http://www.cbs.dtu.dk/services/NetPhos/)

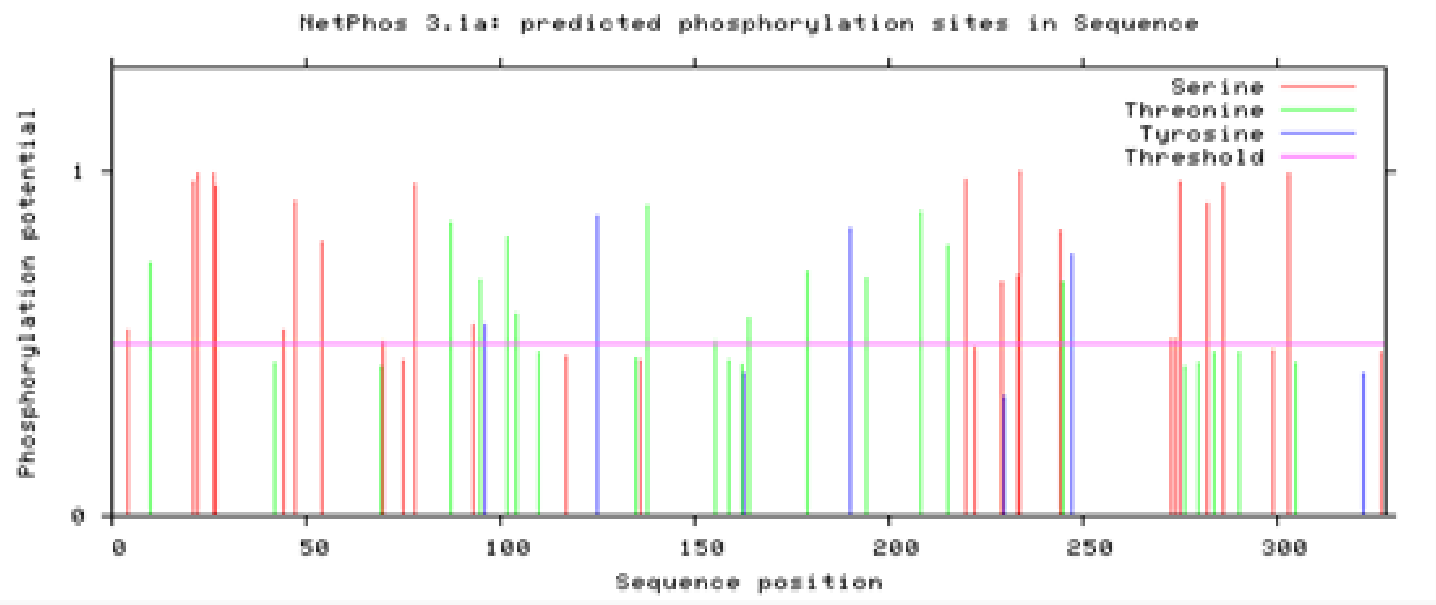


Fig.1d Ramachandran plot of predicted PsbO protein cloned from HD2329 cv. of wheat using RAMPAGE

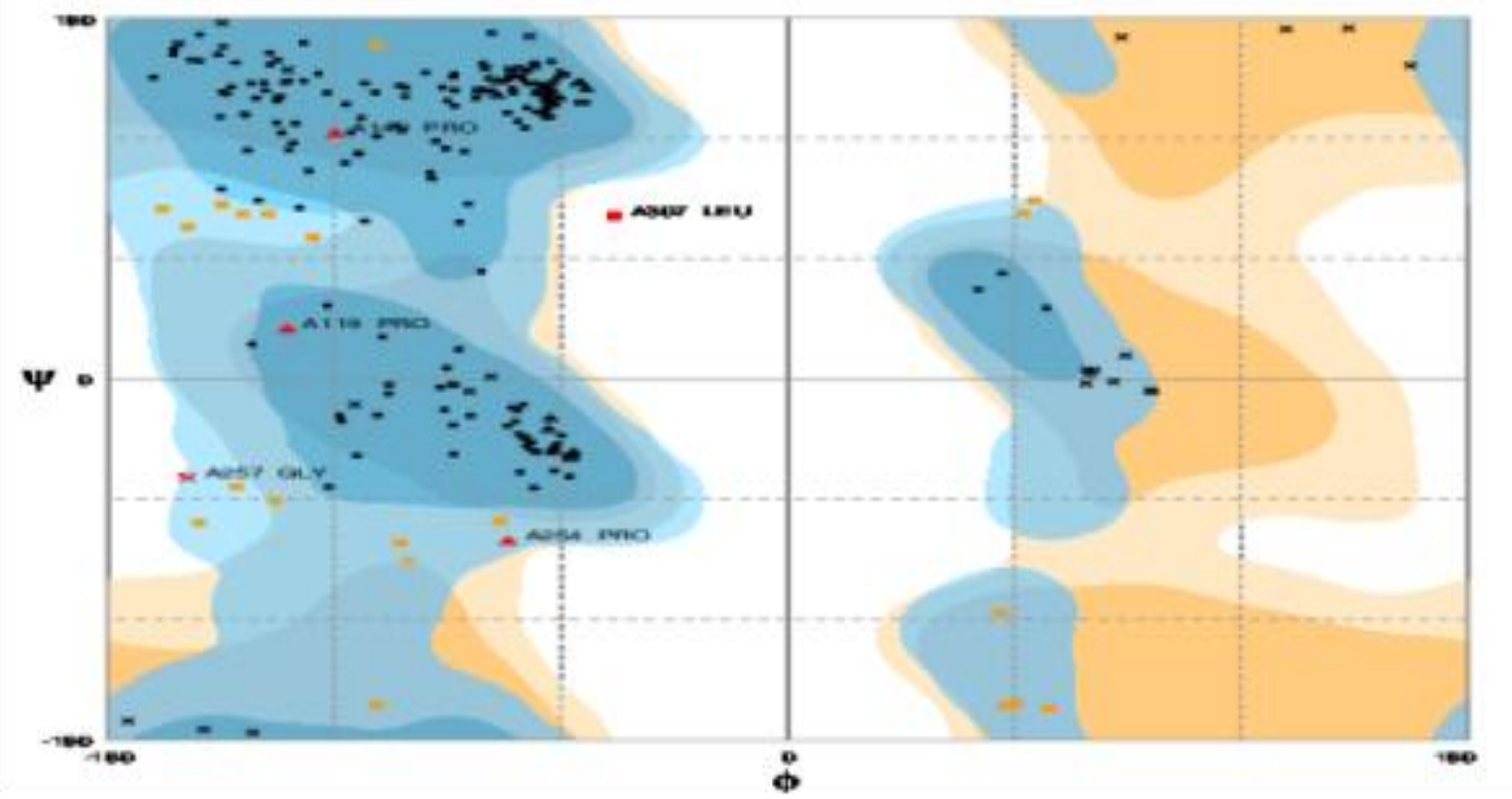

Fig.2 Expression profiling of putative PsbO gene transcript of wheat under differential heat stress at different stages; in thermotolerant cv. HD2985 and thermosusceptible cv. HD2329; C$22^{\circ} \mathrm{C}$; T1- HS of $30^{\circ} \mathrm{C}$ for 1 hour, T2- HS for $38^{\circ} \mathrm{C}$ for $1 \mathrm{~h}$; $\beta$-actin gene was used as endogenous gene control; Relative fold express was calculated by Pfaffl method (Pfaffl, 2002);

Vertical bar indicates SE $(n=3)$

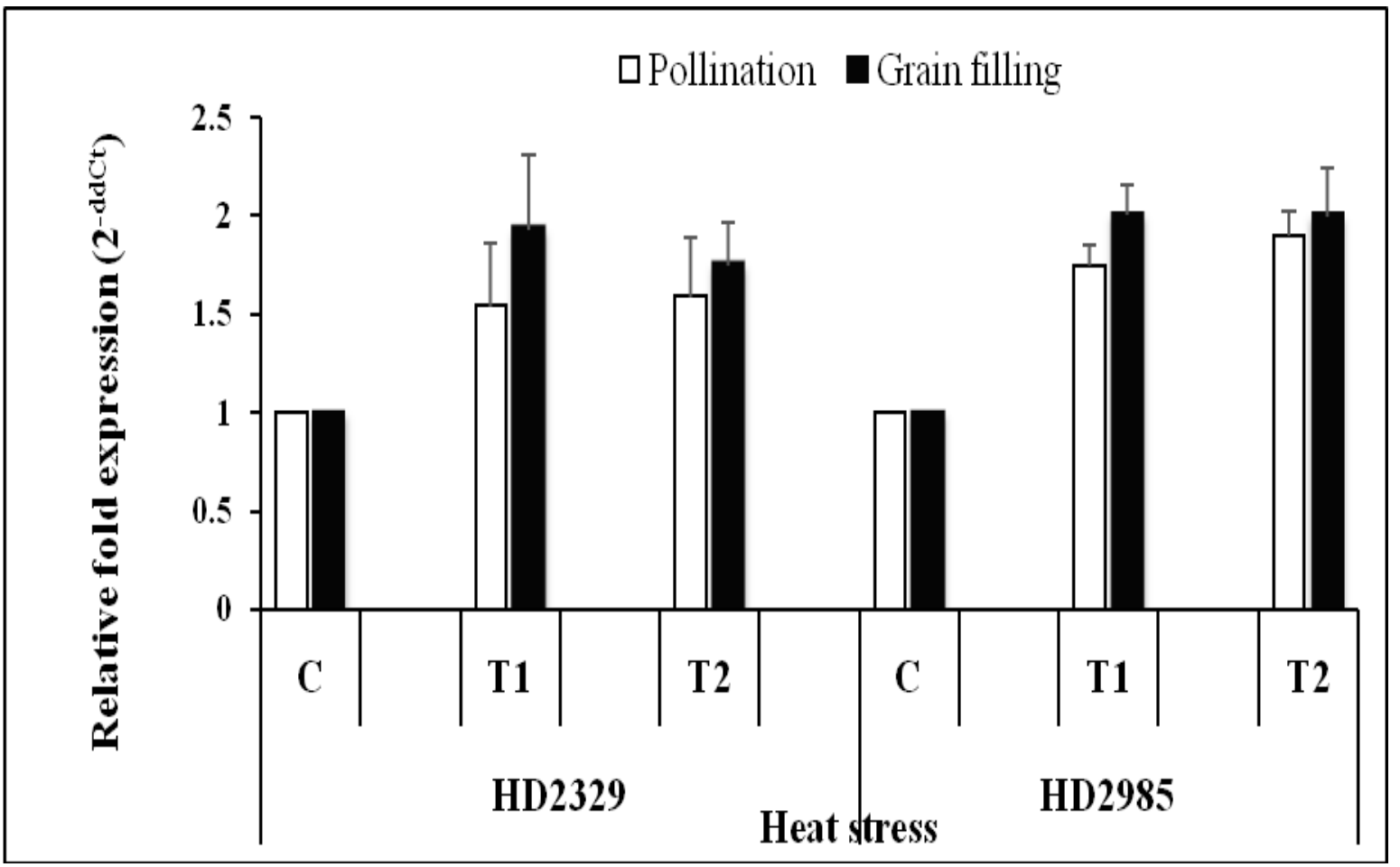


Fig.3 Photosynthetic rate of thermotolerant wheat cv. HD2985 and thermosusceptible cv. HD2329 at pollination and grain-filling stage under differential heat stress treatment; $\mathrm{C}-22^{\circ} \mathrm{C}$;

T1- HS of $30^{\circ} \mathrm{C}$ for $1 \mathrm{~h}$, T2- HS for $38^{\circ} \mathrm{C}$ for $1 \mathrm{~h}$; Vertical bar indicates $\mathrm{SE}(\mathrm{n}=3)$

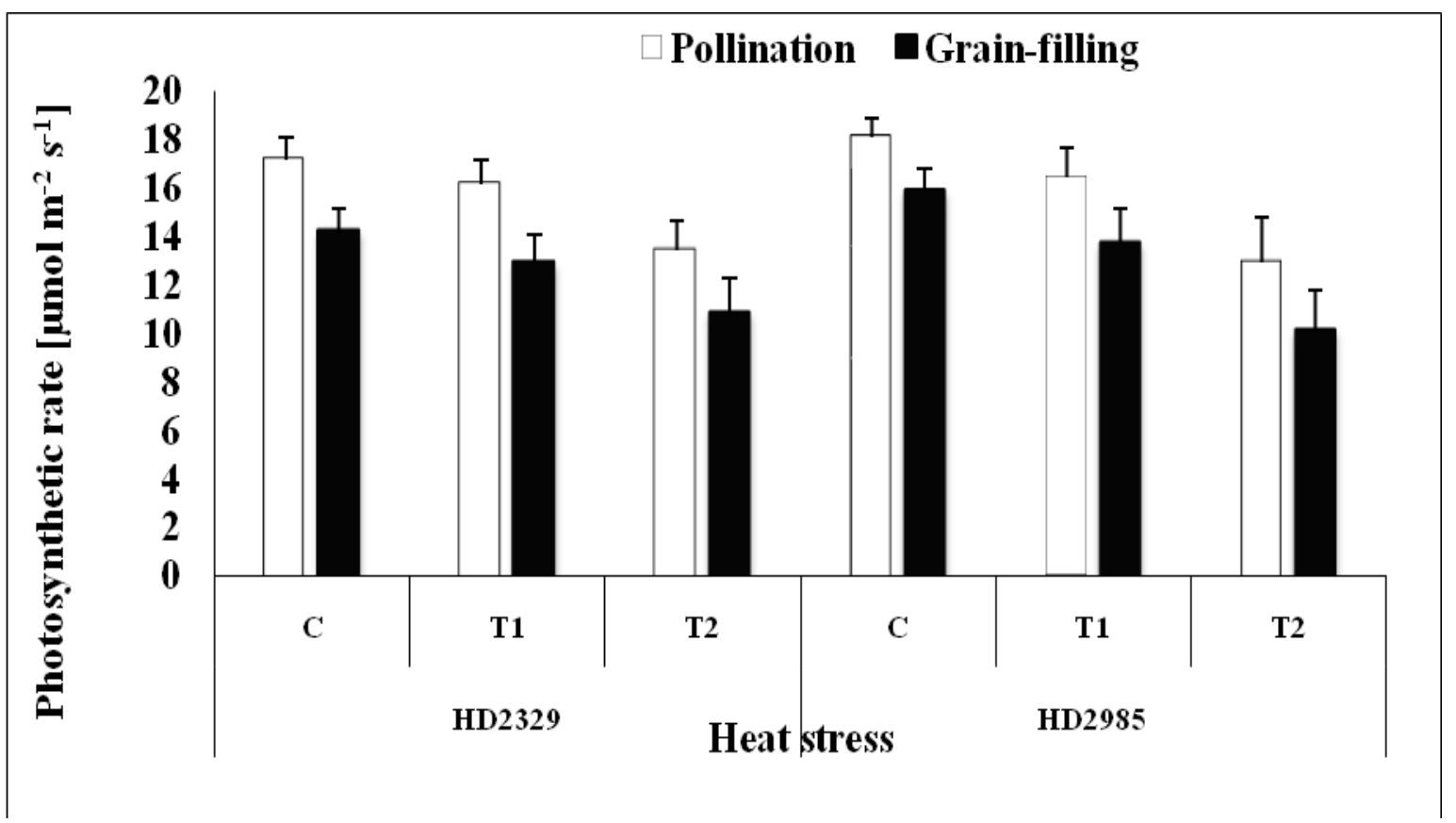

Fig.4 Guaiacol peroxidise (GPX) activity assay in thermotolerant wheat cv. HD2985 and thermosusceptible cv. HD2329 at pollination and grain-filling stage under differential heat stress treatment; C-22 ${ }^{\circ} \mathrm{C}$; T1- HS of $30^{\circ} \mathrm{C}$ for $1 \mathrm{~h}, \mathrm{~T} 2-\mathrm{HS}$ for $38^{\circ} \mathrm{C}$ for $1 \mathrm{~h}$;

Vertical bar indicates SE $(n=3)$

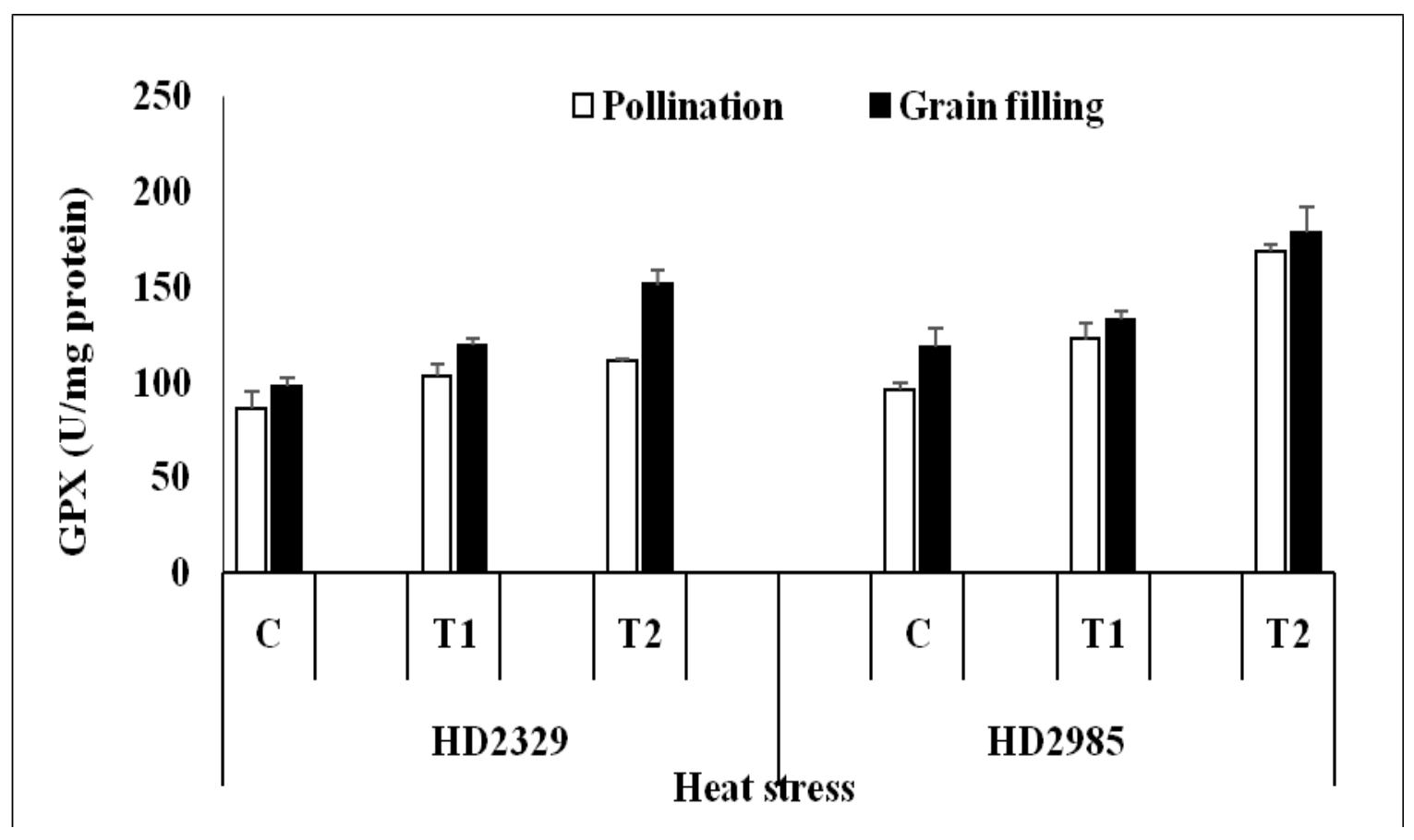


Fig.5 Superoxide dismutase activity assay in thermotolerant wheat cv. HD2985 and thermosusceptible cv. HD2329 at pollination and grain-filling stage under differential heat stress treatment; C-22 $2^{\circ}$; T1- HS of $30^{\circ} \mathrm{C}$ for $1 \mathrm{~h}$, T2- HS for $38^{\circ} \mathrm{C}$ for $1 \mathrm{~h}$;

Vertical bar indicates SE $(n=3)$

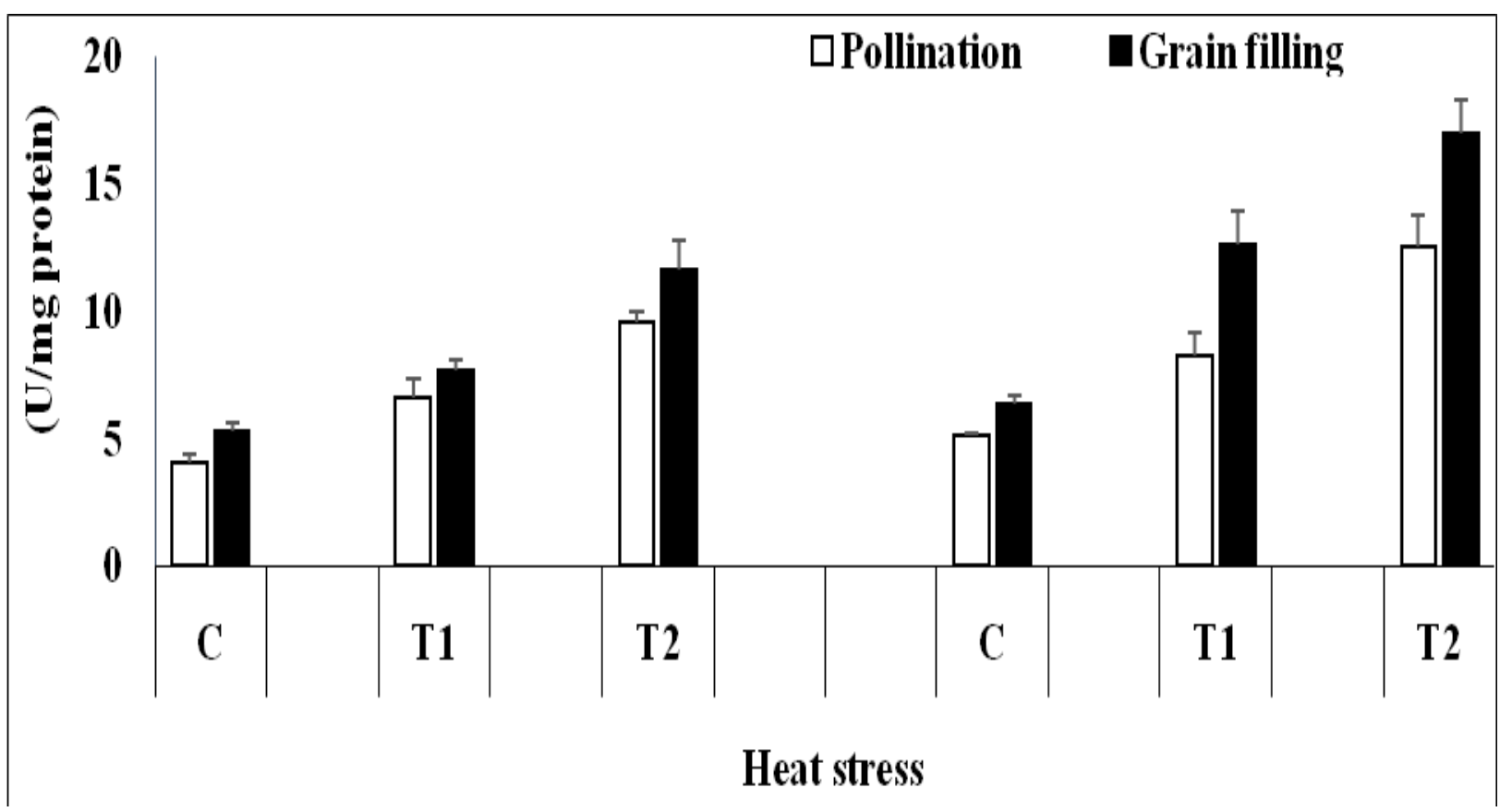

Fig.6 Catalase activity assay in thermotolerant wheat cv. HD2985 and thermosusceptible cv. HD2329 at pollination and grain-filling stage under differential heat stress treatment; C-22 ${ }^{\circ}$; T1- HS of $30^{\circ} \mathrm{C}$ for $1 \mathrm{~h}, \mathrm{~T} 2-\mathrm{HS}$ for $38^{\circ} \mathrm{C}$ for $1 \mathrm{~h}$; Vertical bar indicates $\mathrm{SE}(\mathrm{n}=3)$

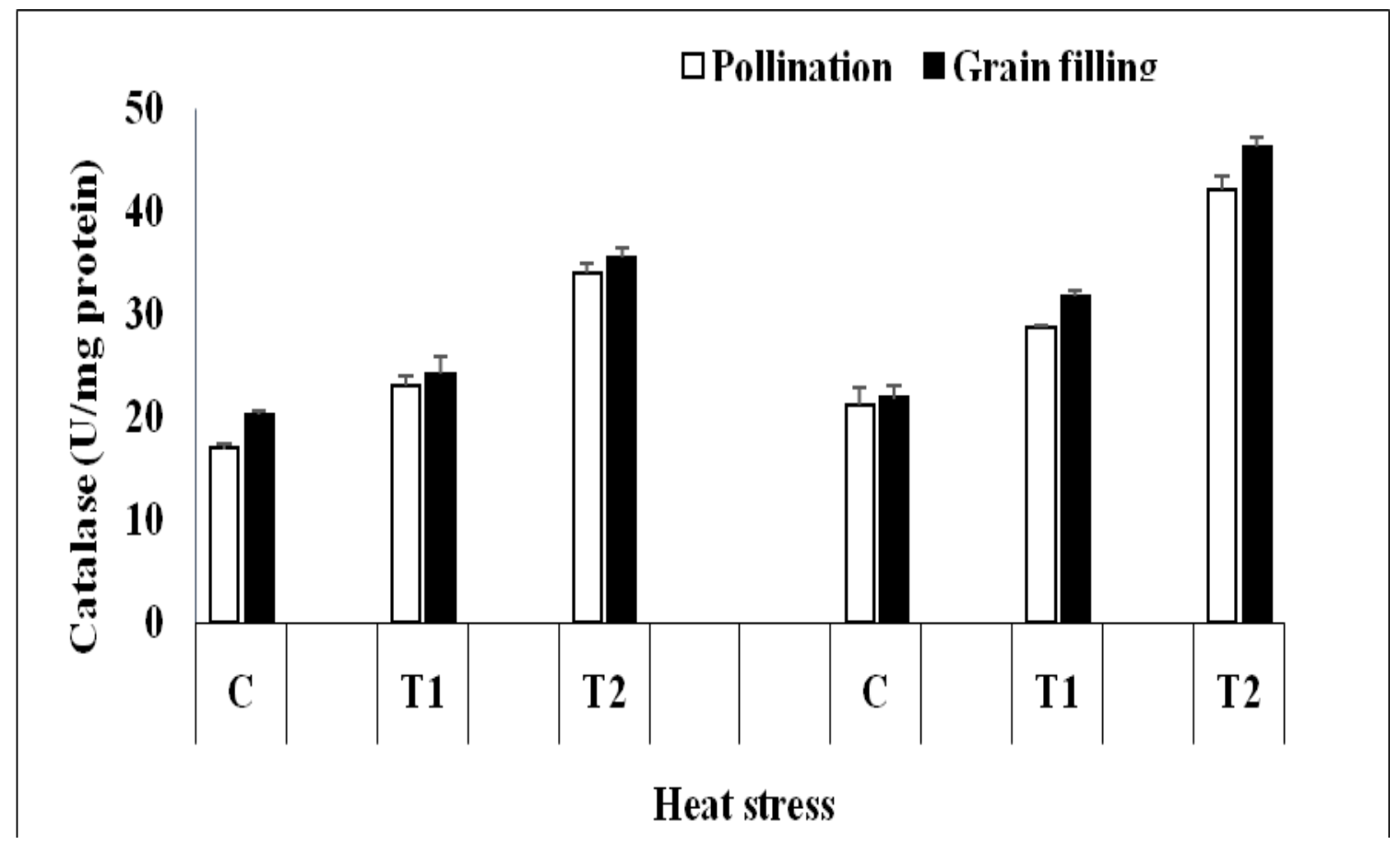


Fig.7 Estimation of Total Antioxidant Capacity (TAC) in thermotolerant wheat cv. HD2985 and thermosusceptible cv. HD2329 at pollination and grain-filling stage under differential heat stress treatment; C-22 ${ }^{\circ} \mathrm{C}$; T1- HS of $30^{\circ} \mathrm{C}$ for $1 \mathrm{~h}$, T2- HS for $38^{\circ} \mathrm{C}$ for $1 \mathrm{~h}$;

Vertical bar indicates SE $(n=3)$

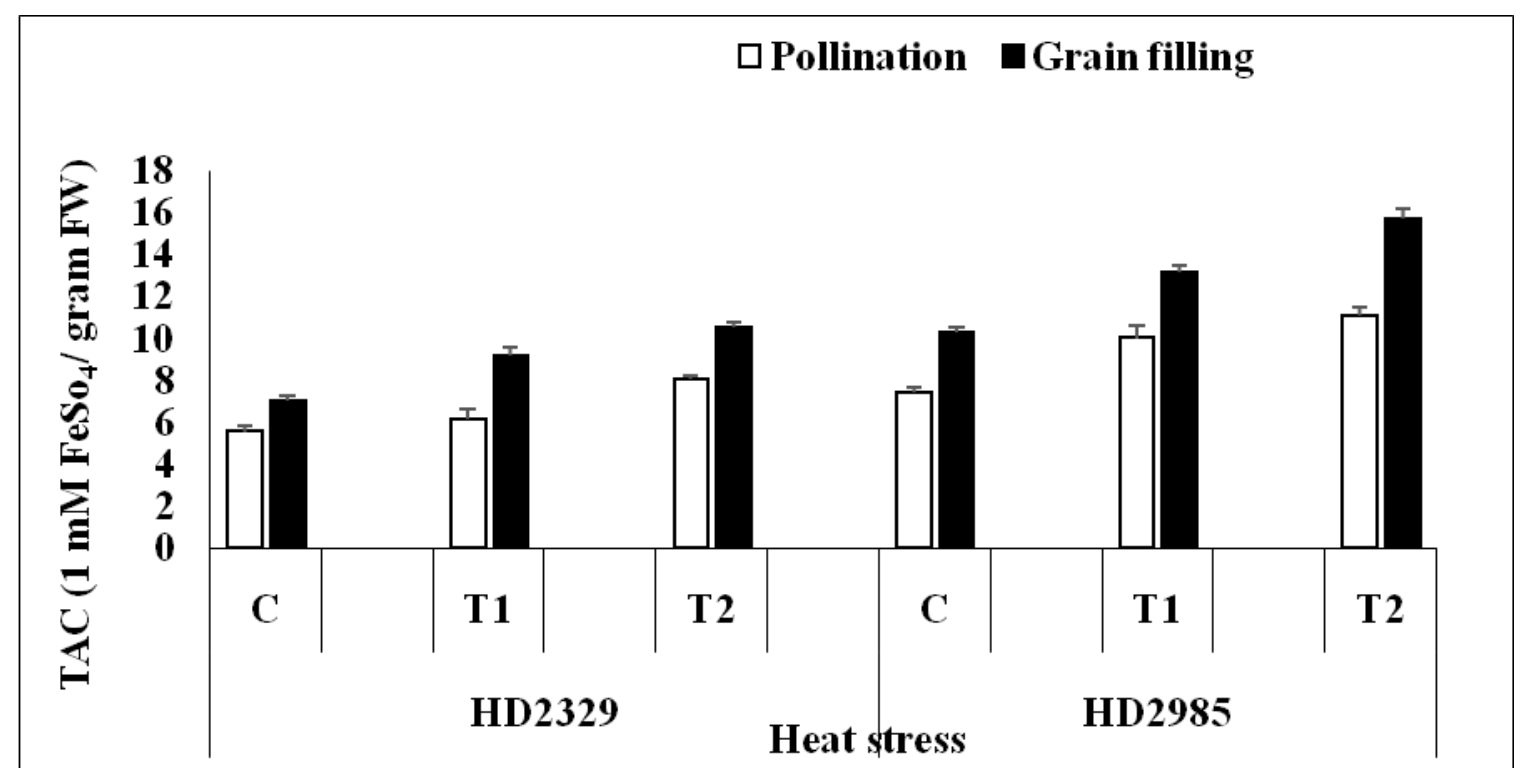

\section{Superoxide dismutase activity assay}

Superoxide dismutase (SOD) is one of important antioxidant enzyme for cellular defense. We observed a significant increase in SOD activity in all the treatment with respect to control in this study. We observed significant increase in SOD in the thermotolerant cultivar (HD2985) than thermo susceptible (HD2329) cultivar at both pollination and grain filling stages under the $\mathrm{HS}$ of $30^{\circ} \mathrm{C}$ and $38^{\circ} \mathrm{C}$. HD2985 showed maximum SOD activity of $12.525 \mathrm{Umg}^{-}$ ${ }^{1}$ protein during pollination stage and 17.03 $\mathrm{Umg}^{-1}$ protein at grain-filling in response to $38^{\circ} \mathrm{C}, 1 \mathrm{~h}$. Similarly, under control condition, we observe SOD activity of $5.1 \mathrm{Umg}^{-1}$ and 6.35 $\mathrm{Umg}^{-1}$ during pollination and grain-filling stages, respectively (Fig. 5). In thermo susceptible cultivar HD2329 the maximum of 9.555 $\mathrm{Umg}^{-1}$ and $11.665 \mathrm{Umg}^{-1}$ was observed at $38^{\circ} \mathrm{C}, 1 \mathrm{~h}$ in pollination and grain-filling stages, respectively which is significantly higher than $30^{\circ} \mathrm{C}$ for $1 \mathrm{~h}\left(\mathrm{~T}_{1}\right)$ and control $\left(22^{\circ} \mathrm{C}\right)$. The observation is in conformity with the findings of He et al., (2005) and Kumar et al., (2012).

\section{Catalase activity assay}

We observed an increased in catalase activity in both the cultivar and with successive treatment. The activity was observed more in thermotolerant cultivar viz. HD2985, than thermosusceptible HD2329. In both the stages of development, the activity was higher with successive treatment of heat stress in both the cultivar. The specific activity of catalase (CAT) was observed maximum of 42.15 $\mu \mathrm{mol} \mathrm{min} \mathrm{mg}^{-1}$ protein to HS of $38^{\circ} \mathrm{C}$ for $1 \mathrm{~h}$ $\left(\mathrm{T}_{2}\right)$ and minimum of $21.15 \mu \mathrm{mol} \mathrm{min} \mathrm{mg}^{-1}$ protein in control condition at pollination stage whereas a maximum of $46.3 \mu \mathrm{mol} \mathrm{min}{ }^{-1}$ $\mathrm{mg}^{-1}$ protein to $\mathrm{HS}$ of $38^{\circ} \mathrm{C}$ for $1 \mathrm{~h}\left(\mathrm{~T}_{2}\right)$ and $21.8 \mu \mathrm{mol} \mathrm{min} \mathrm{mg}^{-1}$ protein at control in grain filling stage of HD2985 (Fig. 6). In thermosusceptible cultivar, HD2329 maximum activity of $34.05 \mu \mathrm{mol} \mathrm{min} \mathrm{mg}^{-1}$ protein and a minimum of $16.9 \mu \mathrm{mol} \mathrm{min}{ }^{-1}$ $\mathrm{mg}^{-1}$ protein at pollination stage and a 
maximum of $35.45 \mu \mathrm{mol} \mathrm{min} \mathrm{mg}^{-1}$ protein and $20.2 \mu \mathrm{mol} \mathrm{min} \mathrm{mg}^{-1}$ protein in grain filling at $38^{\circ} \mathrm{C}$ (HS for $1 \mathrm{~h}$ ) and control respectively. Almeselmani et al., (2006) also showed the higher activity of antioxidant enzymes under heat stress in wheat.

\section{Total antioxidant capacity}

TAC is a measure of the antioxidant potential of the tissues, and is one of the important biochemical parameters used for assessing the thermotolerance of crops. We observed significant increase in TAC in the thermotolerant (HD2985) than thermosusceptible (HD2329) cultivar at both pollination and grain filling stages under HS of $30^{\circ} \mathrm{C}$ and $38^{\circ} \mathrm{C}$. In HD2985 a maximum of $11.055 \mathrm{mmol} \mathrm{g}^{-1} \mathrm{FW}$ at pollination and 15.67 mmol $\mathrm{g}^{-1} \mathrm{FW}$ at grain filling at $38^{\circ} \mathrm{C}$ was observed in comparison to $7.42 \mathrm{mmol} \mathrm{g}^{-1} \mathrm{FW}$, $10.26 \mathrm{mmol} \mathrm{g}^{-1} \mathrm{FW}$ in control at pollination and grain-filling stage respectively. In thermo susceptible cv. HD2329, the maximum of $8.03 \mathrm{mmol} \mathrm{g}^{-1} \mathrm{FW}$ and $10.54 \mathrm{mmol} \mathrm{g}^{-1} \mathrm{FW}$ was observed at $38^{\circ} \mathrm{C}$ in pollination and grainfilling stage, respectively which is significantly higher than $30^{\circ} \mathrm{C}$ for $1 \mathrm{~h}\left(\mathrm{~T}_{1}\right)$ and control $\left(22^{\circ} \mathrm{C}\right)$ (Fig. 7). Increase in the TAC under HS was observed more in thermotolerant cv. The finding is in agreement with the observation of Sairam et al.,(2002) who explained the activities of the antioxidant enzymes involved in thermotolerance goes up under HS; similar observations were reported from our lab also (Kumar et al., 2013 and 2014; de Leonardis et al., 2015).

Heat stress has a severe detrimental effect on wheat. As photosynthesis is the most vulnerable physiological process towards heat, photosystem II act as primary point heat response. In this study, we identified and cloned major extrinsic protein of photosystem II i.e. PsbO (transcript_CDS_52998_unigene
_92869) from HD2329. PsbO was observed to have higher expression in thermotolerant, as compared to thermosusceptible wheat cvs. A positive correlation of $P s b O$ expression was observed with the photosynthetic rate and antioxidant enzymes (GPX, SOD, CAT and TAC) at different stages of wheat growth. There is a need to explore many more PsbO gene in cereals in order to manipulate the carbon assimilatory process under HS.

\section{Acknowledgments}

Authors acknowledge the financial assistance received from ICAR under the NICRA project. We are highly thankful to PG School, IARI.

\section{References}

Almeselmani, M., Deshmukh, P. S., Sairam, R. K., Kushwaha, S. R., and Singh, T. P. 2006. Protective role of antioxidant enzymes under high temperature stress. Plant science, 171(3): 382-388.

Aro, E. M., Virgin, I., and Andersson, B. 1993. Photoinhibition of photosystem II Inactivation, protein damage and turnover. Biochimica et Biophysica Acta (BBA)-Bioenergetics. 1143(2): 113-134.

Asada, K. 2006. Production and scavenging of reactive oxygen species in chloroplasts and their functions. Plant Physiology. 141: 391-396.

Benzie, I.F. and Strain, J.J. 1999. Ferric reducing/antioxidant power assay: Direct measure of total antioxidant activity of biological fluids and modified version for simultaneous measurement of total antioxidant power and ascorbic acid concentration. Methods in Enzymology. 299: 15-27.

Bernacchi, C. J., Pimentel, C., and Long, S. P. 2003. In vivo temperature response functions of parameters required to model RuBP- limited photosynthesis. Plant, Cell and Environment. 26(9): 1419-1430.

Bricker, T. M., and Xu, Q., 1992. Structural 
organization of proteins on the oxidizing side of photosystem II. Two molecules of the $33-\mathrm{kDa}$ manganese-stabilizing proteins per reaction center. Journal of Biological Chemistry. 267(36): 2581625821.

Burrell, M.M. 2003. Starch: the need for improved quality or quantity - an overview. Journal of Experimental Botony. 54(382): 451-456.

Chance, B., and Maehly, A. C. 1955. Assay of catalases and peroxidases. Methods in Enzymology. 2: 764-775.

Chen, Y. E., Zhang, C. M., Su, Y. Q., Ma, J., Zhang, Z. W., Yuan, M., and Yuan, S. 2017. Responses of photosystem II and antioxidative systems to high light and high temperature co-stress in wheat. Environmental and Experimental Botany, 135, 45-55.

Chinnusamy, V., and Khanna- Chopra, R. 2003. Effect of heat stress on grain starch content in diploid, tetraploid and hexaploid wheat species. Journal of agronomy and crop science, 189(4): 242249.

Choulet, F., Alberti, A., Theil, S., Glover, N., Barbe, V., Daron, J., and Leroy, P. 2014. Structural and functional partitioning of bread wheat chromosome 3B. Science. 345(6194): 1249721.

Christensen, J. H., and Christensen, O. B. 2007. A summary of the PRUDENCE model projections of changes in European climate by the end of this century. Climatic Change. 81: 7-30.

De Leonardis, A. M., Fragasso, M., Beleggia, R., Ficco, D. B. M., de Vita, P., and Mastrangelo, A. M. 2015. Effects of heat stress on metabolite accumulation and composition, and nutritional properties of durum wheat grain. International journal of molecular sciences, 16(12): 3038230404.

Enami, I., Yoshihara, S., Tohri, A., Okumura, A., Ohta, H., and Shen, J. R. 2000. Crossreconstitution of various extrinsic proteins and photosystem II complexes from cyanobacteria, red algae and higher plants. Plant and Cell Physiology, 41(12): 1354-1364.

Evers, J., Johnson, M.C. and Marini, M.A. 1994. Peroxidative activities of hemoglobin and hemoglobin derivatives. In: Evers J, Vandegriff KD, Winslow RM (eds.) Methods in Enzymology. (231): 547-561.

Farooq, M., Bramley, H., Palta, J. A., and Siddique, K. H. 2011. Heat stress in wheat during reproductive and grainfilling phases. Critical Reviews in Plant Sciences. 30(6): 491-507.

Hasanuzzaman, M., Nahar, K., Alam, M. M., Roychowdhury, R., and Fujita, M. 2013. Physiological, biochemical, and molecular mechanisms of heat stress tolerance in plants. International Journal of Molecular Sciences. 14(5): 9643-9684.

He, Y., Liu, Y., Cao, W., Huai, M., Xu, B., and Huang, B. 2005. Effects of salicylic acid on heat tolerance associated with antioxidant metabolism in Kentucky bluegrass. Crop Science, 45(3): 988-995.

Henmi, T., Miyao, M., and Yamamoto, Y. 2004. Release and reactive-oxygenmediated damage of the oxygen-evolving complex subunits of PSII during photoinhibition. Plant and Cell Physiology. 45(2): 243-250.

Kim, E. Y., Choi, Y. H., Lee, J. I., Kim, I. H., and Nam, T. J. 2015. Antioxidant Activity of Oxygen Evolving Enhancer Protein 1 Purified from Capsosiphon fulvescens. Journal of Food Science. 80(6): 178-188.

Kimura, A., Eaton-Rye, J. J., Morita, E. H., Nishiyama, Y., and Hayashi, H. 2002. Protection of the oxygen-evolving machinery by the extrinsic proteins of photosystem II is essential for development of cellular thermotolerance in Synechocystis sp. PCC 6803. Plant and cell physiology. 43(8): 932-938.

Kumar R. R. , Goswami S., Singh K., Dubey K., Singh S., SharmaR., Verma N., Kala Y. K., Rai Gyanendra K., Grover M., Mishra D. C., Singh B., Pathak H., Chinnusamy V., Rai A. and Praveen S. 2016. Identification of putative RuBisCo 
Activase (TaRca1) - the catalytic chaperone regulating carbon assimilatory pathway in wheat (Triticum aestivum) under the heat stress. Frontiers in plant science. 7. (doi: 10.3389/fpls.2016.00986)

Kumar R. R., Goswami S., Shamim M., Dubey K., Singh K., Singh S., Kala Y. K., Niraj Ravi R.K., Sakhrey A., Singh G. P., GroverM., Singh B., Rai Gyanendra K., RaiA., Chinnusamy V., and Praveen S. 2017. Exploring the heat-responsive chaperones and microsatellite markers associated with terminal heat stress tolerance in developing wheat. Funct. Integr. Genomics. DOI 10.1007/s10142017-0560-1.

Kumar R.R., Goswami S., Sharma S. K., Singh K., Gadpayle K. A., Kumar Narender, Rai Gyanendra K., Singh Manorama and Rai Raj D. 2012. Protection against heat stress in wheat involves change in cell membrane stability, antioxidant enzymes, osmolyte, $\mathrm{H}_{2} \mathrm{O}_{2}$ and transcript of heat shock protein. International Journal of Plant Physiology and Biochemistry, 4(4), 83-91.

Kumar, R. R., Goswami, S., Singh, K., Rai, G. K., and Rai, R. D. 2013. Modulation of redox signal transduction in plant system through induction of free radical/ROS scavenging redox-sensitive enzymes and metabolites. Australian Journal of Crop Science. 7(11): 1744.

Kumar, R.R. and Rai, R.D. 2014. Can Wheat Beat the Heat: Understanding the Mechanism of Thermotolerance in Wheat (Triticum aestivum L.) A Review. Cereal Research Communications, 42(1): 1-18.

Liu, Z., Xin, M., Qin, J., Peng, H., Ni, Z., Yao, Y., and Sun, Q. 2015. Temporal transcriptome profiling reveals expression partitioning of homeologous genes contributing to heat and drought acclimation in wheat (Triticum aestivum L.). BMC Plant Biology. 15(1): 152.

Lundin, B., Hansson, M., Schoefs, B., Vener, A. V., and Spetea, C. 2007. The Arabidopsis PsbO protein regulates dephosphorylation and turnover of the photosystem II reaction centre D1 protein. The Plant Journal. 49(3): 528-539.

Lundin, B., Nurmi, M., Rojas-Stuetz, M., Aro, E. M., Adamska, I., and Spetea, C. 2008. Towards understanding the functional difference between the two PsbO isoforms in Arabidopsis thalianainsights from phenotypic analyses of psbo knockout mutants. Photosynthesis Research. 98(13): 405-414.

Lundin, B., Thuswaldner, S., Shutova, T., Eshaghi, S., Samuelsson, G., Barber, J., and Spetea, C. 2007. Subsequent events to GTP binding by the plant PsbO protein: structural changes, GTP hydrolysis and dissociation from the photosystem II complex. Biochimica et Biophysica Acta (BBA)-Bioenergetics. 1767(6): 500-508.

McConnell, I. L., Badger, M. R., Wydrzynski, T., and Hillier, W. 2007. A quantitative assessment of the carbonic anhydrase activity in photosystem II. Biochimica et Biophysica Acta (BBA)-Bioenergetics. 1767(6): 639-647.

Murata, N., Takahashi, S., Nishiyama, Y., Allakhverdiev, S.I., 2007. Photoinhibition of photosystem II under environmental stress. Biochimica et Biophysica. Acta 1767, 414- 421.

Offenbacher, A. R., Polander, B. C., and Barry, B. A. 2013. An intrinsically disordered photosystem II subunit, PsbO, provides a structural template and a sensor of the hydrogen-bonding network in photosynthetic water oxidation. Journal of Biological Chemistry. 288(40): 2905629068.

Pawłowicz, I., Kosmala, A., and Rapacz, M. 2012. Expression pattern of the $p s b O$ gene and its involvement in acclimation of the photosynthetic apparatus during abiotic stresses in Festuca arundinacea and Festuca pratensis. Acta Physiologiae Plantarum. 34(5): 1915-1924.

Pfaffl, M.W., Horgan, G.W. and Dempfle, L. 2002. Relative expression software tool (REST()) for group-wise comparison and statistical analysis of relative expression 
results in real-time PCR. Nucleic Acids Research. 30(1):36-41.

Popelkova, H., Commet, A., and Yocum, C. F. 2009. Asp157 is required for the function of PsbO, the photosystem II manganese stabilizing protein. Biochemistry. 48(50): 11920-11928.

Sairam, R. K., Rao, K. V., and Srivastava, G. C. 2002. Differential response of wheat genotypes to long term salinity stress in relation to oxidative stress, antioxidant activity and osmolyte concentration. Plant Science, 163(5): 1037-1046.

Sharkey, T. D. 2005. Effects of moderate heat stress on photosynthesis: importance of thylakoid reactions, Rubisco deactivation, reactive oxygen species, and thermotolerance provided by isoprene. Plant Cell and Environment, 28(3): 269277.

Slafer, G. A. and Satorre, E. H. 1999. Wheat: Ecology and Physiology of Yield Determination. Haworth Press Technology and Industrial, New York

Suzuki, N., and Mittler, R. 2006. Reactive oxygen species and temperature stresses: a delicate balance between signaling and destruction. Physiologia plantarum, 126(1): 45-51.

Svensson, B., Tiede, D. M., and Barry, B. A. 2002. Small-angle X-ray scattering studies of the manganese stabilizing subunit in photosystem II. The Journal of
Physical Chemistry B. 106(34): 84858488.

Takahashi, M., Shigeto, J., Sakamoto, A., and Morikawa, H. 2017. Selective nitration of PsbO1 inhibits oxygen evolution from isolated Arabidopsis thylakoid membranes. Plant Signaling and Behavior. 12(4): 304-342.

Vadez, V., Berger, J. D., Warkentin, T., Asseng, S., Ratnakumar, P., Rao, K. P. C., and Sharma, H. C. 2012. Adaptation of grain legumes to climate change: a review. Agronomy for Sustainable Development. 32(1): 31-44.

Wahid, A., Gelani, S., Ashraf, M. and Foolad, M.R. 2007. Heat tolerance in plants: an overview. Environmental and Experimental Botony.61: 199-223.

Yamamoto, Y., Aminaka, R., Yoshioka, M., Khatoon, M., Komayama, K., Takenaka, D., Yamashita, A., Nijo, N., Inagawa, K., Morita, N., Sasaki, T., Yamamoto, Y., 2008. Quality control of photosystem II: impact of light and heat stress. Photosynthic Research. 98, 589-608.

Yamashita, A., Nijo, N., Pospisil, P., Morita, N., Takenaka, D., Aminaka, R., Yamamoto, Y., 2008. Quality control of photosystem II: reactive oxygen species are responsible for the damage to photosystem II under moderate heat stress. Journal of Biological Chemistry.283, 28380-28391.

\section{How to cite this article:}

Ansif Ali, Suneha Goswami, Ranjeet R. Kumar, Khushboo Singh, Jyoti P. Singh, Ashok Kumar, Arti Kumari, Akshay Sakhrey, Gyanendra K. Rai and Shelly Praveen. 2018. Wheat Oxygen Evolving Enhancer Protein: Identification and Characterization of Mn-Binding Metalloprotein of Photosynthetic Pathway Involved in Regulating Photosytem II Integrity and Network of Antioxidant Enzymes under Heat Stress. Int.J.Curr.Microbiol.App.Sci. 7(02): 177192. doi: https://doi.org/10.20546/ijcmas.2018.702.023 